\title{
Impacts of the January 2005 solar particle event on noctilucent clouds and water at the polar summer mesopause
}

\author{
H. Winkler ${ }^{1}$, C. von Savigny ${ }^{1}$, J. P. Burrows ${ }^{1}$, J. M. Wissing ${ }^{2}$, M. J. Schwartz ${ }^{3}$, A. Lambert ${ }^{3}$, and M. García-Comas ${ }^{4}$ \\ ${ }^{1}$ Institut für Umweltphysik, Universität Bremen, Bremen, Germany \\ ${ }^{2}$ Fachbereich Physik, Universität Osnabrück, Osnabrück, Germany \\ ${ }^{3}$ Jet Propulsion Laboratory, California Institute of Technology, Pasadena, USA \\ ${ }^{4}$ Instituto de Astrofísica de Andalucía - CSIC, Granada, Spain \\ Correspondence to: H. Winkler (hwinkler@iup.physik.uni-bremen.de)
}

Received: 13 December 2011 - Published in Atmos. Chem. Phys. Discuss.: 12 January 2012

Revised: 26 June 2012 - Accepted: 26 June 2012 - Published: 28 June 2012

\begin{abstract}
The response of noctilucent clouds to the solar particle event in January 2005 is investigated by means of icy particle and ion chemistry simulations. It is shown that the decreasing occurrence rate of noctilucent clouds derived from measurements of the SCIAMACHY/Envisat instrument can be reproduced by one-dimensional model simulations if temperature data from the MLS/Aura instrument are used. The model calculations indicate that the sublimation of noctilucent clouds leads to significant changes of the water distribution in the mesopause region. These model results are compared with $\mathrm{H}_{2} \mathrm{O}$ measurements from the MLS and the MIPAS/Envisat satellite instruments. The pronounced modelled water enhancement below the icy particle layer and its decrease during the SPE are not observed by the satellite instruments. At altitudes $>85 \mathrm{~km}$ the satellite measurements show an increase of $\mathrm{H}_{2} \mathrm{O}$ during the SPE in qualitative agreement with the model predictions. The discrepancies between model $\mathrm{H}_{2} \mathrm{O}$ and observations at lower altitudes might be attributed to the one-dimensional model approach which in particular neglects inhomogeneities and horizontal transport processes. Additionally, it is revealed that the water depletion due to reactions of proton hydrates during the considered solar particle event has only a minor impact on the icy particles.
\end{abstract}

\section{Introduction}

It is well established that noctilucent clouds (NLCs) consist of water ice particles which nucleate and grow at the low polar summer mesopause temperatures $(<140 \mathrm{~K})$. The grow- ing particles sediment and become visible at $\sim 84 \mathrm{~km}$ before they eventually sublimate at lower altitudes (e.g. Turco et al., 1982; Jensen and Thomas, 1988; Berger and von Zahn, 2002). Typical NLC radii are in the 10 to $80 \mathrm{~nm}$ range (Rusch et al., 1991; von Cossart et al., 1999; Robert et al., 2009). The uptake of water at higher altitudes and its release at lower altitudes leads to a redistribution of water vapour inside and well below the NLC layer (e.g. von Zahn and Berger, 2003). The temperature measurements of Lübken et al. (2009) indicate that homogeneous ice nucleation can be possible at the polar summer mesopause, see also Murray and Jensen (2010). Condensation nuclei are believed to significantly facilitate the formation of NLC particles, e.g. Gumbel and Megner (2009); Megner and Gumbel (2009). Because the particle cores are likely to be non-ice, the term "icy particles" instead of "ice particles" is used in the following. The growth (or sublimation) rates of icy particles depend significantly on the temperature and on the ambient water vapour pressure. Therefore, NLCs are sensitive to changes in both temperature and water content of the mesopause region (e.g. Jensen et al., 1989; Thomas et al., 1989; von Zahn et al., 2004; Hervig and Siskind, 2006).

After the solar particle event (SPE) in January 2005, when high-energetic protons and electrons of solar and magnetospheric origin entered the polar atmosphere, an abrupt decrease of NLCs was detected, and attributed to the observed temperature increase at the same time (von Savigny et al., 2007). Model studies of Becker and von Savigny (2010) have shown that the increasing temperatures in the upper mesosphere after a SPE are due to changed dynamics: the SPE 
induced ozone loss in the lower mesosphere leads to reduced heating rates which alter the thermal wind balance. This in turn changes the filtering of gravity waves in the mesosphere and causes weaker ascent of air and reduced adiabatic cooling of the NLC region. The systematic analysis of NLC occurrence rates and NLC albedo in relation with solar energetic particle fluxes by Rahpoe et al. (2011) indicates that the effect of NLC depletion due to SPEs is not an exception. However, only after major SPEs, as in July 2000 and January 2005, can the effects clearly be distinguished from the generally high NLC variability.

In addition to the temperature impact on NLCs, there is another possible effect of SPEs due to the increasing ionisation. Reactions of positive water-cluster ions lead to a conversion of $\mathrm{H}_{2} \mathrm{O}$ into $\mathrm{H}+\mathrm{OH}$ (Solomon et al., 1981). This water depletion reduces the local water vapour pressure and potentially affects the growth or sublimation of icy particles.

In this study we investigate the effect of the SPE in January 2005 on NLC by means of atmospheric icy particle and ion chemistry simulations. The model makes use of temperature measurements of the Microwave Limb Sounder (MLS) instrument onboard NASA's Aura satellite. The question of changed atmospheric dynamics is not addressed here.

\section{Description of icy particle growth}

Whether an icy particle grows or shrinks depends on the imbalance of the ambient water vapour pressure $p_{\mathrm{w}}$ and the equilibrium saturation pressure $p_{\text {sat }}$ over the particle. For mesospheric conditions, the radius growth rate $d r / d t$ of a spherical ice particle is given by (Hesstvedt, 1961):

$$
\frac{d r}{d t}=\frac{\alpha\left(p_{\mathrm{w}}-p_{\mathrm{sat}}\right)}{\rho_{\text {ice }}} \sqrt{\frac{m_{\mathrm{w}}}{2 \pi k_{\mathrm{B}} T}}
$$

where $\rho_{\text {ice }} \sim 932 \mathrm{~kg} \mathrm{~m}^{-3}$ is the density of water ice, $m_{\mathrm{w}}$ is the mass of a water molecule, $k_{\mathrm{B}}$ is the Boltzmann constant, $T$ is the temperature in Kelvin, and $\alpha$ is the condensation (or sublimation) coefficient. Commonly, the value $\alpha=0.83$ (Gadsden, 1998) is used.

Due to the curvature of the particle's surface, $p_{\text {sat }}$ is higher than the equilibrium vapour pressure over a plane ice surface $p_{\infty}$. For a spherical particle, $p_{\text {sat }}$ and $p_{\infty}$ are related through the Kelvin equation (e.g. Skinner and Sambles, 1972):

$p_{\text {sat }}=p_{\infty} \exp \left(\frac{2 m_{\mathrm{w}} \sigma}{k_{\mathrm{B}} \operatorname{Tr} \rho_{\mathrm{ice}}}\right)$

with $\sigma$ being the surface tension of ice/vapour, and $r$ the particle radius. $p_{\infty}$ significantly increases with temperature, and due to the surface tension, $p_{\text {sat }}$ increases with decreasing particle size (Kelvin effect). To the authors best knowledge, there are no direct measurements of the water saturation pressure over ice of cubic structure in the range of the polar summer mesopause temperatures. For hexagonal ice there is a useful fit by Murphy and Koop (2005) for $p_{\infty}$ in Pascal valid for temperatures down to $110 \mathrm{~K}$ :

$$
\begin{aligned}
p_{\infty} & =\exp (9.550426-5723.265 / T \\
& +3.53068 \ln (T)-0.00728332 T)
\end{aligned}
$$

This saturation pressure is used in the NLC model of Bardeen et al. (2010), and similar values based on the expression $\ln \left(p_{\infty}\right)=28.548-6077.4 / T( \pm 5 \%$ difference with respect to Eq. (3) for $T=110-150 \mathrm{~K}$ ) have frequently been used in NLC research, e.g. Jensen and Thomas (1988); Berger and von Zahn (2002); Chu et al. (2003). Following these studies, here the saturation pressure corresponding to hexagonal ice is used.

The surface tension in Eq. (2) is both dependent on temperature and particle radius, and can be expressed by Berger and von Zahn (2002):

$\sigma=\frac{0.0141-1.5 \times 10^{-4} T}{1+0.3 / r}$

- the resulting value is in units of $\mathrm{N} \mathrm{m}^{-1}$ for the particle radius $r$ in nanometers. Equation (4) is a combination of the temperature dependent ice-vapour surface tension (Hale and Plummer, 1974) in the numerator, and a factor accounting for the decrease of the surface tension with radius $(1+2 \delta / r)^{-1}$ (Tolman, 1949). $\delta$ is an emperical factor for very small water or ice particles for which the value $\delta=1.5 \times 10^{-10} \mathrm{~m}$ of Turco et al. (1982) is used.

\section{Nucleation}

A molecular description of the formation of ice and icy particles would be desirable but is currently not available. Therefore the classic droplet nucleation theory is widely used in the field of NLC research. In the framework of this theory it is assumed that there is a steady state population of cluster molecules, and the rate at which stable ice embryos are formed, the nucleation rate, can be estimated through thermodynamic considerations (Keese, 1989; Pruppacher and Klett, 1997).

The presence of pre-existing particles which act as condensation nuclei $(\mathrm{CN})$ can significantly facilitate the nucleation (heterogeneous nucleation). A review of different suggested CN candidates is given by Rapp and Thomas (2006). A crucial and not well known parameter for the calculation of the heterogeneous nucleation rate is the contact angle between the nucleus' surface and the ice cap forming on the nucleus. Due to their believed high abundance, meteoric smoke particles have long been the "nuclei of choice" (Rapp and Thomas, 2006). For typical summer mesopause conditions, radii around $1 \mathrm{~nm}$ are required for smoke particles to act as CN (Gumbel and Megner, 2009). The model studies of Megner (2010) have shown that the resulting NLC brightness and NLC ice mass are only weakly dependent on the 
actual $\mathrm{CN}$ concentration, provided that there are enough $\mathrm{CN}$ of $1 \mathrm{~nm}$ radius, i.e. more than about $10 \mathrm{~cm}^{-3}$. Height profiles of $\mathrm{CN}$ based on the one-dimensional model studies of meteoric smoke particle formation and distribution by Hunten et al. (1980) have been used in various NLC models (e.g. Turco et al., 1982; Jensen and Thomas, 1988; Klostermeyer, 1998; Berger and von Zahn, 2002). However, more recent global model studies (Bardeen et al., 2008; Megner et al., 2008) indicate that due to the meridional transport of meteoric material, the smoke particle concentration at the summer pole is significantly smaller. As a consequence, the nucleation rates of icy particles would be much smaller than previously assumed. It has been suggested that the charging of smoke particles would facilitate the nucleation of icy particles by reducing or removing the critical radius of nucleation and increasing the wettability of the smoke particles (Gumbel and Megner, 2009; Megner and Gumbel, 2009). Unfortunately, not much is known about the charging properties of particles in the sub-nanometer range.

\section{Ion chemistry of the NLC region}

Under quiet ionospheric conditions, the principal source of ionisation at the summer mesopause is solar extreme ultraviolet radiation, in particular Lyman- $\alpha$ ionisation of nitric oxide, and the typical charge density is of the order of $10^{3} \mathrm{~cm}^{-3}$ (Gumbel et al., 2003). During a solar particle event, the precipitating energetic particles lead to significantly increased ionisation. For the SPE in January 2005 the charge density exceeds $10^{5} \mathrm{~cm}^{-3}$ (Sect. 7).

The lower thermosphere is primarily composed of $\mathrm{O}_{2}^{+}$and $\mathrm{NO}^{+}$. At lower altitudes, there is production of $\mathrm{O}_{4}^{+}$via the three-body reaction

$\mathrm{O}_{2}^{+}+\mathrm{O}_{2}+\mathrm{M} \rightarrow \mathrm{O}_{4}^{+}+\mathrm{M}$

This leads to the formation of cluster molecules, starting with

$\mathrm{O}_{4}^{+}+\mathrm{H}_{2} \mathrm{O} \rightarrow \mathrm{O}_{2}^{+}\left(\mathrm{H}_{2} \mathrm{O}\right)+\mathrm{O}_{2}$

From $\mathrm{O}_{2}^{+}\left(\mathrm{H}_{2} \mathrm{O}\right)$, proton hydrates $\mathrm{H}^{+}\left(\mathrm{H}_{2} \mathrm{O}\right)_{n}$ and other positive cluster ions are produced. There are different pathways of cluster reactions involving proton hydrates, e.g.:

$\mathrm{O}_{2}^{+}\left(\mathrm{H}_{2} \mathrm{O}\right)+\mathrm{H}_{2} \mathrm{O} \rightarrow \mathrm{H}^{+}\left(\mathrm{H}_{2} \mathrm{O}\right)(\mathrm{OH})+\mathrm{O}_{2}$

$\mathrm{H}^{+}\left(\mathrm{H}_{2} \mathrm{O}\right)(\mathrm{OH})+\mathrm{H}_{2} \mathrm{O} \rightarrow \mathrm{H}^{+}\left(\mathrm{H}_{2} \mathrm{O}\right)_{2}+\mathrm{OH}$

$\mathrm{H}^{+}\left(\mathrm{H}_{2} \mathrm{O}\right)_{2}+n \mathrm{H}_{2} \mathrm{O} \rightarrow \mathrm{H}^{+}\left(\mathrm{H}_{2} \mathrm{O}\right)_{n+2}$

$\mathrm{H}^{+}\left(\mathrm{H}_{2} \mathrm{O}\right)_{n+2}+\mathrm{e} \rightarrow \mathrm{H}+(n+2) \mathrm{H}_{2} \mathrm{O}$

The net effect of the Reactions (R1)-(R6) is a depletion of water:

$\mathrm{O}_{2}^{+}+\mathrm{H}_{2} \mathrm{O}+\mathrm{e} \rightarrow \mathrm{O}_{2}+\mathrm{H}+\mathrm{OH}$
Note that this does not depend on the number of clustering steps (Reaction R5), i.e. the size of the proton hydrates. There are related reactions involving proton hydrates which also lead to a conversion of $\mathrm{H}_{2} \mathrm{O}$ into $\mathrm{H}+\mathrm{OH}$ (Solomon et al., 1981). The ion chemical water depletion is expected to increase with the increasing ionisation during a SPE, and potentially affects icy NLC particles by lowering the ambient water vapour pressure. However, while the relative abundance of water-cluster ions below $\sim 80 \mathrm{~km}$ is large, the positive ion chemistry at higher altitudes is dominated by $\mathrm{O}_{2}^{+}$ and $\mathrm{NO}^{+}$. As a matter of coincidence, the transition from ion cluster molecules to molecular ions takes place in the altitude region of the icy particles (Friedrich and Torkar, 1988) and the efficiency of water depletion decreases drastically with height (Solomon et al., 1981).

There is an additional interference between ion chemistry and NLCs. In the presence of icy particles, so-called bite outs in the electron density are observed (Ulwick et al., 1988). The decreased free electron densities are due to the charge capture by the icy particles (Reid, 1990). Under quiet ionospheric conditions, there are pronounced electron bite outs in the icy particle layer, and the growth rate of proton hydrates can be enhanced (Gumbel and Witt, 2002). However, for higher ionisation rates as during a SPE, the electron density overwhelms the icy particle density and the effect of particle charging is of minor importance (Gumbel et al., 2003).

\section{Measurement data}

Data originating from different satellite instruments are used in this study:

1. The NLC occurrence rates originate from ultraviolet limb radiance measurements by the Scanning Imaging Absorption spectroMeter for Atmospheric CHartographY (SCIAMACHY) (Bovensmann et al., 1999). SCIAMACHY is onboard ESA's Envisat spacecraft in a sun-synchronous orbit. The local time windows of the measurements at $70-80^{\circ} \mathrm{S}$ used for this study are 11:30 p.m.-03:00 a.m. and 05:00-8.30 a.m. Used are daily mean zonally averaged NLC occurence rates. The data set is the same as the one shown in von Savigny et al. (2007). For further details on the SCIAMACHY NLC observations see von Savigny et al. (2004).

2. The Microwave Limb Sounder (MLS) onboard NASA's Earth Observing System Aura satellite provides several data products. For the purpose of this study, temperature (Schwartz et al., 2008) and water (Read et al., 2007; Lambert et al., 2007) are used (data product version 3.3). The local time windows of the measurements at $70-80^{\circ} \mathrm{S}$ used for this study are 03:15-05:15 p.m. and 10:05 p.m.-00:00. Used are daily mean zonally averaged values. The MLS data are retrieved on pressure levels. In order to convert them to geometric altitude, the 
MLS geopotential height (Schwartz et al., 2008) is used. The geometric altitude $z$ and the geopotential height $H$ are related as

$$
z=\frac{H}{1-H / R_{\mathrm{E}}}
$$

where $R_{\mathrm{E}}$ is the radius of the Earth $(6378.1370 \mathrm{~km})$. Equation (5) follows from the definition of the geopotential height, e.g. Andrews et al. (1987), and the inverse-square law of gravity. The vertical resolution of MLS water and temperature in the NLC altitude region is of the order $8-15 \mathrm{~km}$. This resolution does not allow the NLC layer to be resolved, but the measurements provide valuable information about the average conditions of the NLC region. In particular, the temperature increase after the SPE is clearly observed (as already shown in the paper of von Savigny et al., 2007).

3. The Michelson Interferometer for Passive Atmospheric Sounding (MIPAS) onboard Envisat observes infrared emissions from water molecules with high resolution up to the mesopause. The water vapor abundance used here is derived from MIPAS spectra using the IMK/IAA (Institut für Meteorologie und Klimaforschung/Instituto de Astrofísica de Andalucía) data processor, which includes the GRANADA non-local thermodynamic equilibrium algorithm (von Clarmann et al., 2003). This allows for accurate $\mathrm{H}_{2} \mathrm{O}$ retrievals in the atmospheric regions where its emissions are affected by non-LTE, i.e. above $50 \mathrm{~km}$ and particularly in the polar summer. Used are daily mean zonally averaged values. The local time windows of the measurements at $70-80^{\circ} \mathrm{S}$ used for this study are 11:30 p.m.-03:00 a.m. and 05:00-08:30 a.m. The vertical resolution is about $6 \mathrm{~km}$ in the NLC altitude region.

\section{Model description}

\subsection{Background atmosphere}

For the studies presented here, a one-dimensional model of the altitude range $75-91 \mathrm{~km}$ at latitude $75^{\circ} \mathrm{S}$ is used. It is initialised with trace gas profiles for polar summer conditions from a two-dimensional atmospheric chemistry and transport model (Winkler et al., 2009), and it has the same photochemistry routines. The transport of the trace gases is calculated by solving the one-dimensional advection-diffusion equation for the mixing ratio $X$ at time $t$ and altitude $z$ (Jensen et al., 1989):

$$
\frac{\partial X}{\partial t}=-\left(w+\frac{K_{z}}{H}\right) \frac{\partial X}{\partial z}+K_{z} \frac{\partial^{2} X}{\partial z^{2}}
$$

where $w$ is the vertical wind speed, $H$ the atmospheric scale height, and $K_{z}$ the diffusion coefficient. Molecular diffusion is neglected, and for $K_{z}$ the eddy diffusion coefficient profile for polar summer conditions from Table 3 in Lübken (1997) is used. The vertical wind is assumed to linearly increase from $1.5 \mathrm{~cm} \mathrm{~s}^{-1}$ at $75 \mathrm{~km}$ to $4 \mathrm{~cm} \mathrm{~s}^{-1}$ at $85 \mathrm{~km}$, and then linearly decrease to $2 \mathrm{~cm} \mathrm{~s}^{-1}$ at $91 \mathrm{~km}$. This resembles the vertical wind profile of Rapp and Thomas (2006). Equation (6) is solved by the means of the Crank-Nicolson mass operator scheme (Fletcher, 1988) on an equidistant grid of $50 \mathrm{~m}$ resolution. The transported constituents are: $\mathrm{H}_{2} \mathrm{O}, \mathrm{CH}_{4}, \mathrm{H}, \mathrm{OH}$, $\mathrm{HO}_{2}, \mathrm{O}_{3}, \mathrm{O}, \mathrm{N}$, and NO.

An important model parameter is the water mixing ratio at the lower boundary at $75 \mathrm{~km}$. It is prescribed by $\mathrm{H}_{2} \mathrm{O}$ values from either MLS or MIPAS measurements poleward of $70^{\circ} \mathrm{S}$. A note: the vertical resolution of both satellite instruments is several to many $\mathrm{km}$ (Sect. 5). In principle it could be possible that due to the vertical averaging, the measurement data would miss an effect of the SPE at $75 \mathrm{~km}$ which due to upward transport would affect the water concentration in the model domain. However, simulations (not shown) of the January 2005 SPE with the two-dimensional model described in Winkler et al. (2009) have revealed that the impact on $\mathrm{H}_{2} \mathrm{O}$ at altitudes $\sim 70-78 \mathrm{~km}$ is small. This justifies use of a fixed $\mathrm{H}_{2} \mathrm{O}$ at the lower model boundary.

\subsection{Icy particle model}

The NLC particles are simulated as spherical icy particles. Their growth and shrinkage according to Eq. (1) is calculated by an Eulerian approach (advection in the radius domain). The numerical method is the same as in the model of Toon et al. (1988). Considered are 20 non-equally spaced radius bins from 3 to $305 \mathrm{~nm}$. The bin size distribution is geometric; the center radius of the $i$-th bin is $r_{i}=r_{1} \times 2^{(i-1) / 3}$ with $r_{1} \sim 3.4 \mathrm{~nm}$.

The model accounts for photodecomposition of water molecules at the surface of the NLC particles due to Lyman$\alpha$ radiation (Murray and Plane, 2005), assuming Mie absorption and a unity quantum yield for production of $\mathrm{H}+\mathrm{OH}$. The absorption coefficients have been calculated with the MiePlot program (Laven, 2003), using the complex refractive index $1.3963+0.24 i$ for ice at $121 \mathrm{~nm}$ (Warren, 1984).

The NLC transport processes considered are sedimentation, advection and diffusion. Following Berger and von Zahn (2002), an effective eddy diffusion coefficient of $K_{z} / 4$ has been assumed for the icy particles. The sedimentation speed is calculated using the formula of Reid (1975). For model runs covering more than a few days, the effect of the meridional transport has to be considered. Therefore, a removal rate of $2 \times 10^{-6} \mathrm{~s}^{-1}$ for the NLC particles due to meridional winds is used. This corresponds to a removal time constant of about 5 days, and is in agreement with typical meridional wind speeds of $5 \mathrm{~m} \mathrm{~s}^{-1}$ in the upper mesosphere (Singer et al., 2005) and a latitudinal extent of the NLC region of $20^{\circ}$. 
Table 1. UBIC species.

\begin{tabular}{ll}
\hline Cations & $\mathrm{N}^{+}, \mathrm{N}_{2}^{+}, \mathrm{NO}^{+}, \mathrm{NO}_{2}^{+}, \mathrm{O}^{+}, \mathrm{O}_{2}^{+}, \mathrm{O}_{4}^{+}, \mathrm{O}_{5}^{+}, \mathrm{H}^{+}, \mathrm{CO}^{+}, \mathrm{CO}_{2}^{+}, \mathrm{HCO}^{+}$, \\
& $\mathrm{H}_{2} \mathrm{O}^{+}, \mathrm{O}_{2}^{+}\left(\mathrm{H}_{2} \mathrm{O}\right), \mathrm{H}^{+}\left(\mathrm{H}_{2} \mathrm{O}\right)_{n=1} \ldots 10, \mathrm{H}^{+}\left(\mathrm{H}_{2} \mathrm{O}\right)(\mathrm{OH}), \mathrm{H}^{+}\left(\mathrm{H}_{2} \mathrm{O}\right)\left(\mathrm{CO}_{2}\right)$, \\
& $\mathrm{H}^{+}\left(\mathrm{H}_{2} \mathrm{O}\right)_{2}\left(\mathrm{CO}_{2}\right), \mathrm{H}^{+}\left(\mathrm{H}_{2} \mathrm{O}\right)\left(\mathrm{N}_{2}\right), \mathrm{H}^{+}\left(\mathrm{H}_{2} \mathrm{O}\right)_{2}\left(\mathrm{~N}_{2}\right), \mathrm{NO}^{+}\left(\mathrm{H}_{2} \mathrm{O}\right)$, \\
& $\mathrm{NO}^{+}\left(\mathrm{H}_{2} \mathrm{O}\right)_{2}, \mathrm{NO}^{+}\left(\mathrm{H}_{2} \mathrm{O}\right)_{3}, \mathrm{NO}^{+}\left(\mathrm{CO}_{2}\right), \mathrm{NO}^{+}\left(\mathrm{N}_{2}\right), \mathrm{NO}^{+}\left(\mathrm{H}_{2} \mathrm{O}\right)\left(\mathrm{CO}_{2}\right)$, \\
& $\mathrm{NO}^{+}\left(\mathrm{H}_{2} \mathrm{O}\right)_{2}\left(\mathrm{CO}_{2}\right), \mathrm{NO}^{+}\left(\mathrm{H}_{2} \mathrm{O}\right)\left(\mathrm{N}_{2}\right), \mathrm{NO}^{+}\left(\mathrm{H}_{2} \mathrm{O}\right)_{2}\left(\mathrm{~N}_{2}\right), \mathrm{NO}_{2}^{+}\left(\mathrm{H}_{2} \mathrm{O}\right)_{n=1,2}$ \\
\hline Anions & $e, X^{-}$ \\
\hline Neutrals & $\left.\mathrm{N}\left({ }^{4} \mathrm{~S}\right), \mathrm{N}\left({ }^{2} \mathrm{D}\right), \mathrm{N}_{2}, \mathrm{O}^{3} \mathrm{P}\right), \mathrm{O}\left({ }^{1} \mathrm{D}\right), \mathrm{O}_{2}, \mathrm{O}_{3}, \mathrm{NO}, \mathrm{NO}_{2}, \mathrm{NO}_{3}, \mathrm{~N}_{2} \mathrm{O}$, \\
& $\mathrm{H}, \mathrm{H}_{2}, \mathrm{OH}, \mathrm{HO}_{2}, \mathrm{H}_{2} \mathrm{O}, \mathrm{CH}_{4}, \mathrm{CH}_{3}, \mathrm{CO}_{2}, \mathrm{CO}$ \\
\hline
\end{tabular}

The model uses MLS temperatures. It is not possible to derive reliable information about the diurnal temperature variations from the MLS data because the effect of the changing geolocation of the measurements mixes with temporal changes. In order to account for the pronounced diurnal and semi-diurnal variations of NLCs (von Zahn et al., 1998; Chu et al., 2001), at altitudes $>81 \mathrm{~km}$ temperature variations are superimposed on the daily mean MLS temperatures. Based on the harmonic fit parameters of Chu et al. (2003), the phase of the diurnal and the semi-diurnal temperature variations are $9 \mathrm{~h}$ and $1.5 \mathrm{~h}$, respectively. The amplitudes of both diurnal and semi-diurnal variation are $2 \mathrm{~K}$. These values have been chosen to reproduce the diurnal temperature variations of the Forbes and Gillette (1982) model at $60^{\circ} \mathrm{S}$ at the December solstice, see Fig. 3 in Jensen et al. (1989). As disscused in Jensen et al. (1989), the model of Bjarnason (1987) predicts larger tidal amplitudes of $\sim 4 \mathrm{~K}$ for $65^{\circ} \mathrm{N}$ during summer. This is in agreement with temperature observation at the polar summer mesopause in the Northern Hemisphere (Singer et al., 2003; Stevens et al., 2010). We have performed additional model simulations with a diurnal amplitude of $4 \mathrm{~K}$, and a semi-diurnal amplitude of $2 \mathrm{~K}$. The results of these simulations (not shown) do not differ significantly from the results assuming a $2 \mathrm{~K}$ diurnal amplitude, and would not change the conclusions drawn here. The diurnal variations in vertical winds and eddy diffusion have only minor effects on NLCs (Jensen et al., 1989), and are therefore neglected. To account for the temperature difference between particles and the ambient air (e.g. Rapp and Thomas, 2006), a linear temperature increase with radius has been assumed, reaching $1 \mathrm{~K}$ for a particle of $60 \mathrm{~nm}$ radius. The model does not simulate condensation nuclei. For simplicity, a constant number density of $100 \mathrm{~cm}^{-3}$ icy particles in the smallest radius bin $(3-3.8 \mathrm{~nm})$ is prescribed. The advantage of this approach is that it avoids assumptions concerning the $\mathrm{CN}$ size distribution and the wettability (see Sect. 3). Complementarily, test simulations have been performed with a calculated heterogeneous nucleation rate of particles in the smallest radius bin according to classic droplet nucleation theory using the parameters given by Rapp and Thomas (2006). For this purpose, a CN size distribution $n(r)=n_{0} \exp \left(-r / r_{0}\right)$ was assumed, where $n(r)$ is the number density of $\mathrm{CN}$ of radius $r$. The parameters $n_{0}=2 \times 10^{5} \mathrm{~cm}^{-3}$ and $r_{0}=0.11 \mathrm{~nm}$ were estimated from Fig. 7 in the article of Megner and Gumbel (2009). Note that these values are based on two-dimensional transport simulations (Megner et al., 2008) and result in significantly less $\mathrm{CN}$ than, e.g. in the studies of Klostermeyer (1998) and Rapp and Thomas (2006). Therefore, the CN have to have a very high wettability to cause sufficient formation of icy particles. For simplicity, perfect wettability is assumed. Figure 1 shows the modelled icy particle distribution during one day. The model version with fixed $100 \mathrm{~cm}^{-3}$ icy particles in the smallest radius bin yields generally more NLC particles and slightly larger ice density than the model run with calculated nucleation. However, the general NLC pattern is the same in both model versions. While the number density of icy particles peaks at $\sim 86 \mathrm{~km}$, the highest ice density occurs about $3 \mathrm{~km}$ lower in the atmosphere. This is due to the sedimentation of the growing particles. There are two local maxima of the total ice mass in agreement with NLC observations at the South pole (Chu et al., 2003). The particle radii (not shown) are largest in the altitude range $80-83 \mathrm{~km}$. At $81.5 \mathrm{~km}$, the mean particle radius varies between $30 \mathrm{~nm}$ and $80 \mathrm{~nm}$, being largest during the second ice mass maximum in the afternoon. The fraction of particles with radius $>120 \mathrm{~nm}$ is always smaller than $1 \%$. All of this applies to both model versions. In order to avoid the aforementioned uncertainties concerning the nucleation process, in the following only results from the model with prescribed $100 \mathrm{~cm}^{-3}$ icy particles in the smallest radius bin are shown. Model runs (not shown) with number densities in the range $10-1000 \mathrm{~cm}^{-3}$ do not give significantly different results, in accordance with the findings of Megner (2010).

\subsection{Ion chemistry model}

The effect of the precipitating protons and electrons during the SPE is accounted for by ionisation rates from AIMOS (Atmospheric Ionization Module Osnabrück) (Wissing et al., 2009). The ion reactions are simulated with the University of Bremen Ion Chemistry (UBIC) model. The UBIC version used here differs in some respects from the one of Winkler et al. (2009). It accounts only for positive ions being relevant in the mesosphere and lower thermosphere, electrons, 

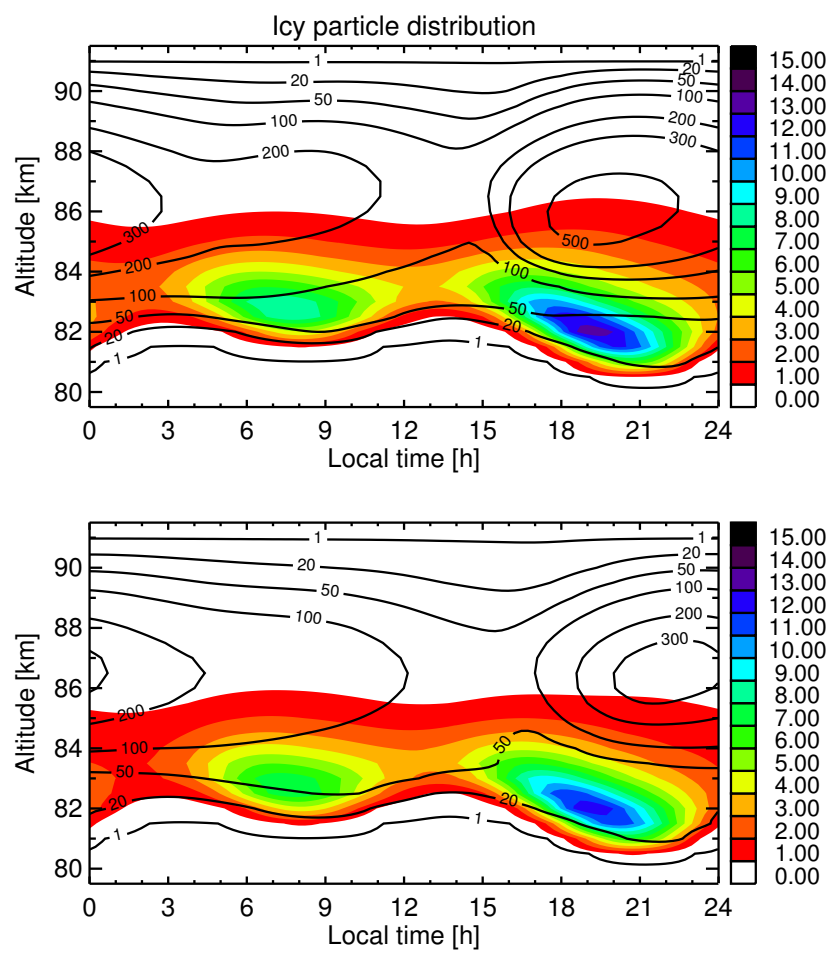

Fig. 1. Modelled icy particles at $75^{\circ} \mathrm{S}$ during the period of one day (14 January). The black contour lines indicate the total number of icy particles per $\mathrm{cm}^{3}$, and the filled color contours show the total ice mass in units of $10^{-15} \mathrm{~g} \mathrm{~cm}^{-3}$. The particles in the smallest radius bin are excluded. Upper panel: simulation with prescribed $100 \mathrm{~cm}^{-3}$ icy particles in the smallest radius bin. Lower panel: simulation with calculated heterogeneous nucleation assuming perfect wettability of the $\mathrm{CN}$ (for details see Sect. 6.2).

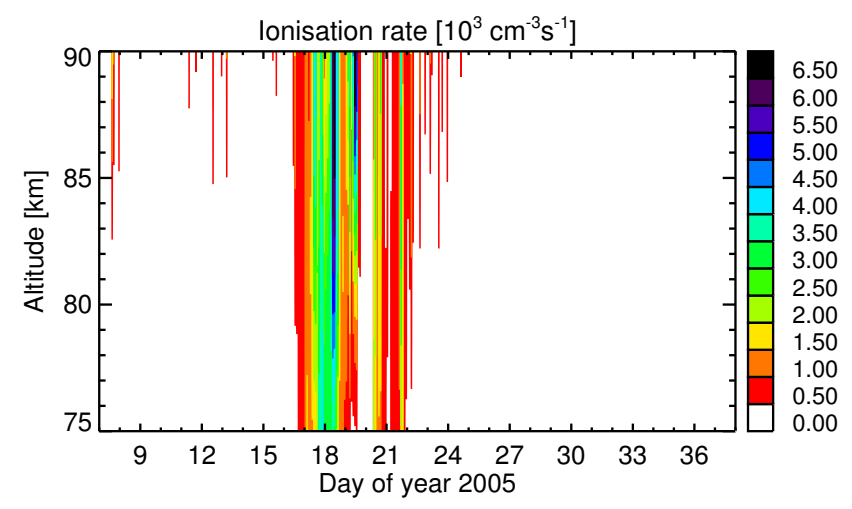

Fig. 2. Zonal mean ionisation rate due to precipitating protons and electrons averaged between $72-82^{\circ} \mathrm{S}$ for days 7-38 of year 2005 originating from the AIMOS model (Sect. 6.3).

and a pseudo-species $X^{-}$. The latter stands for all negative atoms and molecules. Table 1 lists the species included in the model. The negative ion chemistry is not resolved. This is a suitable approach as most of the negative charges are free electrons in the altitude region of interest. Proton hy-

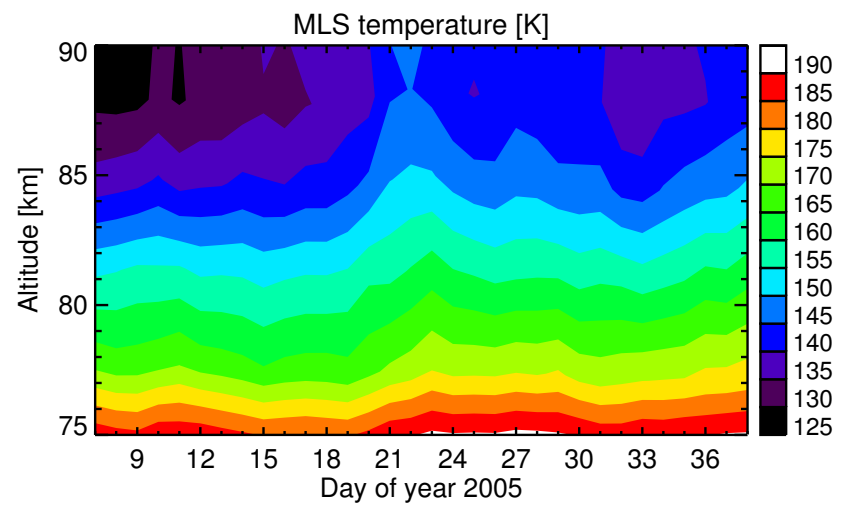

Fig. 3. Zonally averaged daily mean MLS temperature for latitudes $70-80^{\circ} \mathrm{S}$ for days $7-38$ of year 2005 .

drates $\mathrm{H}^{+}\left(\mathrm{H}_{2} \mathrm{O}\right)_{n}$ up to $n=10$ are included in the model. For the conditions considered in this study, the concentration of heavier proton hydrates turned out to be negligible. For the growth of proton hydrates, $\mathrm{H}^{+}\left(\mathrm{H}_{2} \mathrm{O}\right)_{n}+\mathrm{H}_{2} \mathrm{O} \rightarrow$ $\mathrm{H}^{+}\left(\mathrm{H}_{2} \mathrm{O}\right)_{n+1}$, a Langevin reaction rate of $10^{-9} \mathrm{~cm}^{3} \mathrm{~s}^{-1}$ is applied as the cluster growth turns from temperature dependent three-body reactions into second order reactions at lower temperatures (Lau et al., 1982). Following Gumbel et al. (2003), the rate coefficients for unimolecular decomposition of the proton hydrates are determined by detailed balancing between cluster growth and decomposition. The rate coefficients for recombination of small proton hydrates with electrons given by Leu et al. (1973) are used, and for $n \geq 6$ they are taken to be $2.9 \times 10^{-6} \sqrt{300 / T} n^{1 / 3} \mathrm{~cm}^{3} \mathrm{~s}^{-1}$ reproducing the size-dependence proposed by Gumbel et al. (2003).

In order to account for the effect of electron capture by icy particles, the latter are allowed to get negatively charged. The charge capture is not simulated in detail. It is simply assumed that icy particles instantaneously acquire one elementary charge (provided that the electron density is high enough).

\section{Results}

The two main forcings during the SPE in January 2005 are ionisation and temperature increase. Figure 2 displays the ionisation rates due to precipitating protons and electrons. There is significantly increased ionisation during 16-22 January with highest values on 18 January. In Fig. 3 the MLS temperatures are depicted. All MLS data shown in this section are daily mean zonally averaged values. Averaged are all MLS measurements in the latitude band $70-80^{\circ} \mathrm{S}$ during one day. Used are MLS profiles from both the acsending (03:15-05:15 p.m.) and the descending node (10:05 p.m.00:00). Similarly, the SCIAMACHY and MIPAS data presented are averages of all measurements in the latitude band $70-80^{\circ} \mathrm{S}$ during one day. All of these measurements fall in 

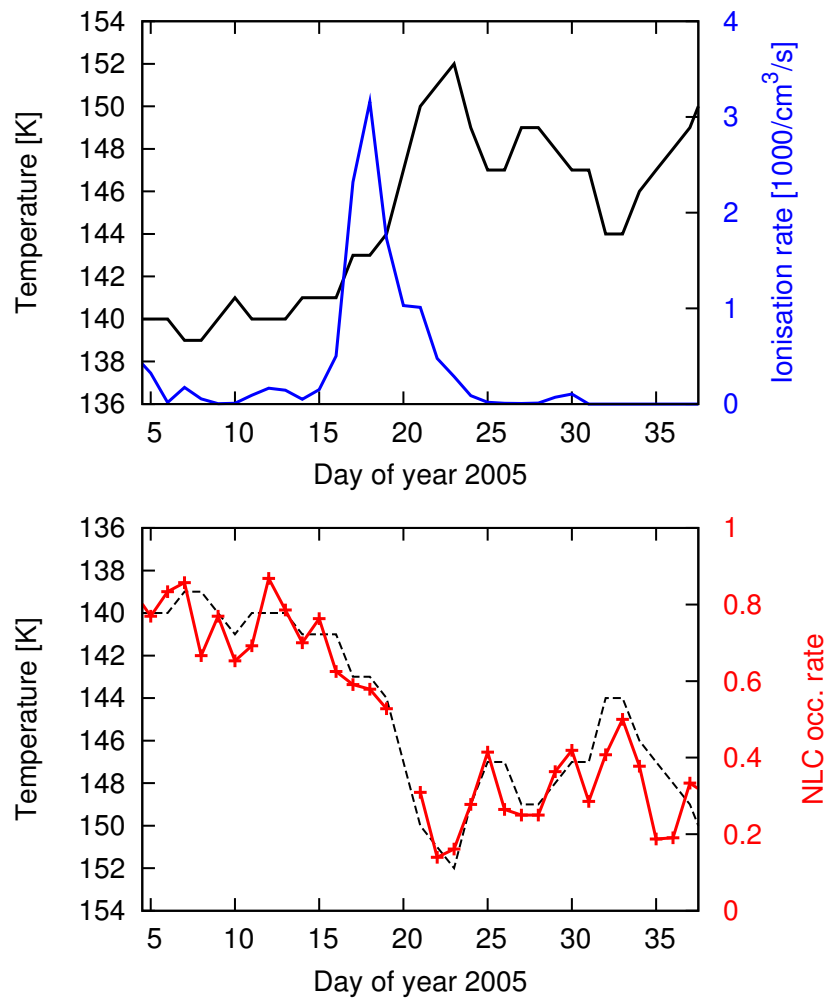

Fig. 4. Upper panel: (black solid line) zonally averaged $\left(70-80^{\circ} \mathrm{S}\right)$ daily mean MLS temperature averaged between $80-90 \mathrm{~km}$, and (blue line) zonally averaged $\left(72-82^{\circ} \mathrm{S}\right)$ daily mean ionisation rate averaged between $80-90 \mathrm{~km}$. Lower panel: (red line with crosses) daily mean NLC occurrence rate from SCIAMACHY measurements $\left(70-80^{\circ} \mathrm{S}\right)$, and (dashed black line) MLS temperature with reversed axis orientation.

the time periods 11:30 p.m.-03:00 a.m. and 05:00-8.30 a.m. Figure 4 shows both ionisation rate and temperature averaged between 80 and $90 \mathrm{~km}$ (top) as well as the NLC occurrence rate derived from SCIAMACHY measurements in comparison with the varying temperature (bottom). Note that there is a time lag between the highest ionisation and the temperature maximum on 21-23 January. There is a clear anti-correlation of temperature with the observed NLC occurrence rate. The latter starts to decrease after 15 January, when both ionisation and temperature increase. In order to assess the impacts of the two factors, model simulations have been performed. Unless otherwise stated, the water mixing ratio at the model's lower boundary at $75 \mathrm{~km}$ is prescribed by zonally averaged daily mean MLS measurements. As a first step, the model was run with MLS temperatures but without ion chemistry. Figure 5 shows the resulting distribution of icy particles during the January 2005 SPE. Due to the temperature increase, there is significant sublimation of icy particles, and their number density is drastically reduced, in particular during the temperature maximum on 21-23 January. There is a weak recovery of icy particles during 24-25 January, another

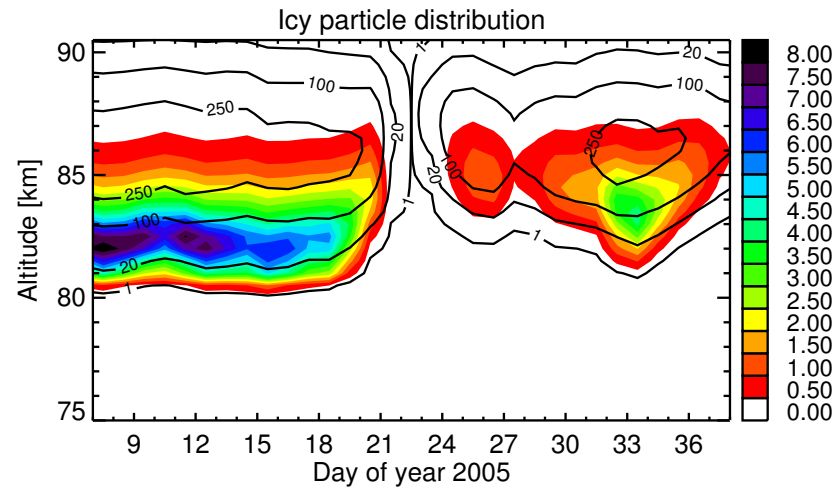

Fig. 5. Modelled icy particles at $75^{\circ} \mathrm{S}$ around the SPE January 2005 with MLS temperatures, and without ion chemistry (see text for details). The solid contour lines show the total number of icy particles per $\mathrm{cm}^{3}$, and the color contours depict the total ice mass in units of $10^{-15} \mathrm{~g} \mathrm{~cm}^{-3}$. The particles in the smallest radius bin are excluded.

minimum on 27 January, followed by increasing ice density and again a decrease towards 7 February (38th day of year).

The daily satellite data used here are averages of all observations in limited time windows corresponding to the satellites' overpass times. For the purpose of comparison, the model output has been averaged over these time windows. For the comparison with MLS, the model was averaged over 03:15-05:15 p.m. and 10:05 p.m.-00:00. For SCIMACHY and MIPAS comparison, the model was averaged over 11:30 p.m.-03:00 a.m. and 05:00-8.30 a.m.

Figure 6 displays the total icy particle column and the total ice column as a function of time from different model runs in comparison with the SCIAMACHY NLC occurrence rates. The model results are in general agreement with the SCIAMACHY occurrence rates, the NLC decrease after January 15 th and also the smaller peaks after the SPE are reproduced by the simulation. However, the model overestimates the effect of sublimation and predicts a complete disappearance of icy particles during the temperature maximum on 21-23 January in contrast to the SCIAMACHY data. Therefore, additional model runs have been performed with reduced temperatures, also indicated in Fig. 6. If the MLS temperatures are lowered by a few Kelvin, the model results agree better with the observations. In particular the complete sublimation of particles during 21-23 January is avoided with MLS temperatures lowered by 2 or $5 \mathrm{~K}$. In the following, results from model runs with MLS temperatures minus $2 \mathrm{~K}$ are shown. $2 \mathrm{~K}$ is well inside the uncertainties of the MLS data in the considered altitude range. The precision of individiual MLS temperature profiles is about $\pm 2.5 \mathrm{~K}$, and there is a modelled bias uncertainty of $(2 \pm 3) \mathrm{K}$ (Schwartz et al., 2008). The fact that our model results agree better with the NLC observations if the MLS temperatures are lowerd by $2 \mathrm{~K}$ does not necessarily mean that the MLS temperatures are too high. It might be that the simple one-dimensional model using 

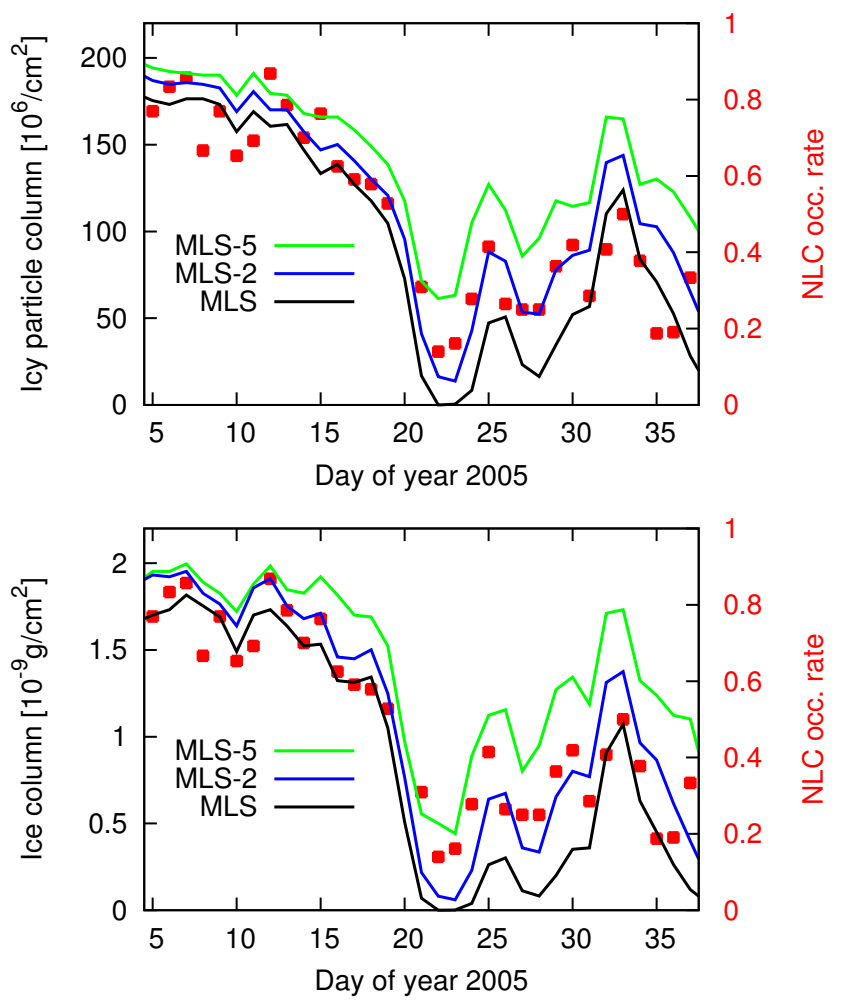

Fig. 6. Upper panel: total column of icy particles in units of $10^{6} \mathrm{~cm}^{-2}$ for three model simulations at $75^{\circ} \mathrm{S}$ with different temperatures: (black line) MLS temperature field, (blue line) MLS temperatures minus $2 \mathrm{~K}$, and (green line) MLS temperature minus $5 \mathrm{~K}$ as well as (red dots) NLC occurrence rate from SCIAMACHY measurements. Lower panel: as the upper panel, but total ice column in units of $10^{-9} \mathrm{~g} \mathrm{~cm}^{-2}$. The particles in the smallest radius bin are excluded. The model results are averages for the time period of the SCIAMACHY measurements (Sect. 5).

zonally averaged daily mean temperatures overestimates the icy particle sublimation as it neglects variations of the threedimensional temperature field, and three-dimensional transport. On the other hand, Hervig and Gordley (2010) have pointed out that for limb measurements, the retrieved temperature is a line-of-sight mean which is indeed generally higher than the ice temperature. Compared to temperature data from the SABER (Sounding of the Atmosphere using Broadband Emission Radiometry) instrument (Mlynczak and Russell, 1995) the MLS temperature has a negative bias uncertainty of up to $9 \mathrm{~K}$ (Schwartz et al., 2008). MLS temperatures in combination with SABER data have been used in the assimilation system NOGAPS-ALPHA (Hoppel et al., 2008; Eckermann et al., 2009). A comparison of the MLS temperatures used in our study with the corresponding assimilated temperatures (not shown) does not reveal a clear pattern. The MLS temperatures tend to be smaller (typically $1-3 \mathrm{~K}$ ) than the assimilated ones. However, during the temperature maximum on 21-23 January, the NOGAP-ALPHA temperatures are smaller $(1-4 \mathrm{~K})$ than the MLS temperatures. The differ-

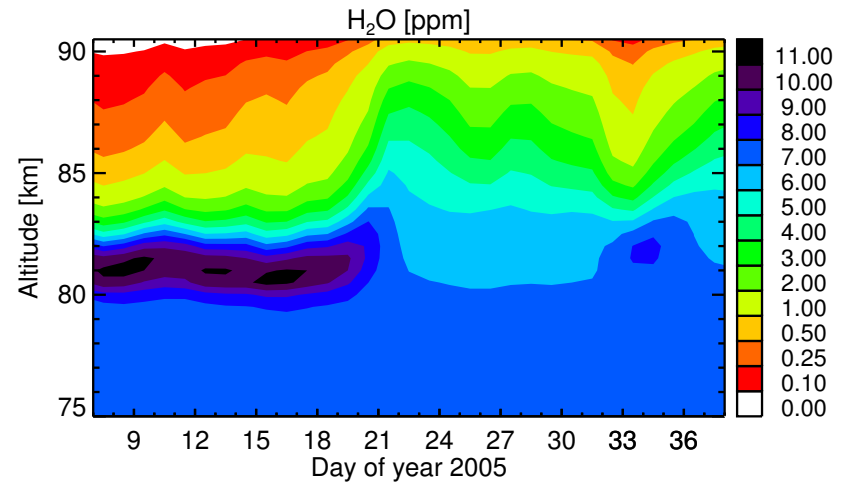

Fig. 7. Modelled daily mean water mixing ratio $[\mathrm{ppm}]$ at $75^{\circ} \mathrm{S}$ around the SPE January 2005.

ences might partly be due to fact that the temperatures used here are MLS data version 3.3 whereas the assimilation system used version 2.2. No final conclusion can be drawn from this comparison without further investigation.

Corresponding to the changing icy particle abundance during and after the SPE, there is a significant impact on the modelled water distribution. Before the SPE, the water abundance just below the icy particle layer is significantly enhanced, see Fig. 7. Between $80-82 \mathrm{~km}$, the $\mathrm{H}_{2} \mathrm{O}$ mixing ration reaches $11 \mathrm{ppm}$, compared to $\sim 6 \mathrm{ppm}$ after the icy particles have disappeared. At higher altitudes the uptake of water by the icy particles reduces the water concentration, and due to the sublimation of the icy particles during the SPE, the water abundance increases, e.g. from $\sim 0.5$ to $\sim 5.5 \mathrm{ppm}$ at $86 \mathrm{~km}$. The MLS water measurements (Fig. 8) do not show such a pronounced effect. However, due to the limited vertical resolution of the MLS measurements, small-scale structures are not expected to show up in the MLS data. For comparison, Fig. 8 also depicts the modelled water vertically smoothed with a $12 \mathrm{~km}$ boxcar function. The smoothed model result still shows a stronger effect than the MLS data. There is a moderate increase of the MLS water mixing ratio during 19-22 January at higher altitudes. The pronounced modelled water enhancement below the icy particle layer and its decrease during the SPE cannot be seen in the MLS data. The slight decrease of MLS $\mathrm{H}_{2} \mathrm{O}$ at altitudes $<80 \mathrm{~km}$ during the SPE should not be considered sigificant. At altitudes $>85 \mathrm{~km}$ MLS shows an increase of $\mathrm{H}_{2} \mathrm{O}$ during the SPE in agreement with the model results. However, the observed $\mathrm{H}_{2} \mathrm{O}$ increase is smaller than the modelled one. The discrepancies between model $\mathrm{H}_{2} \mathrm{O}$ and observations might be due to missing transport processes in the model, e.g. through meridional winds, which should reduce the effect of freeze-drying and water redistribution to lower altitudes.

While the MLS $\mathrm{H}_{2} \mathrm{O}$ mixing ratio at $75 \mathrm{~km}$ is of the order $7.5 \mathrm{ppm}$, the MIPAS $\mathrm{H}_{2} \mathrm{O}$ mixing ratio at that altitude is $\sim 5.5 \mathrm{ppm}$. Therefore, additional model runs have been performed with the MIPAS value at the model's lower boundary. 

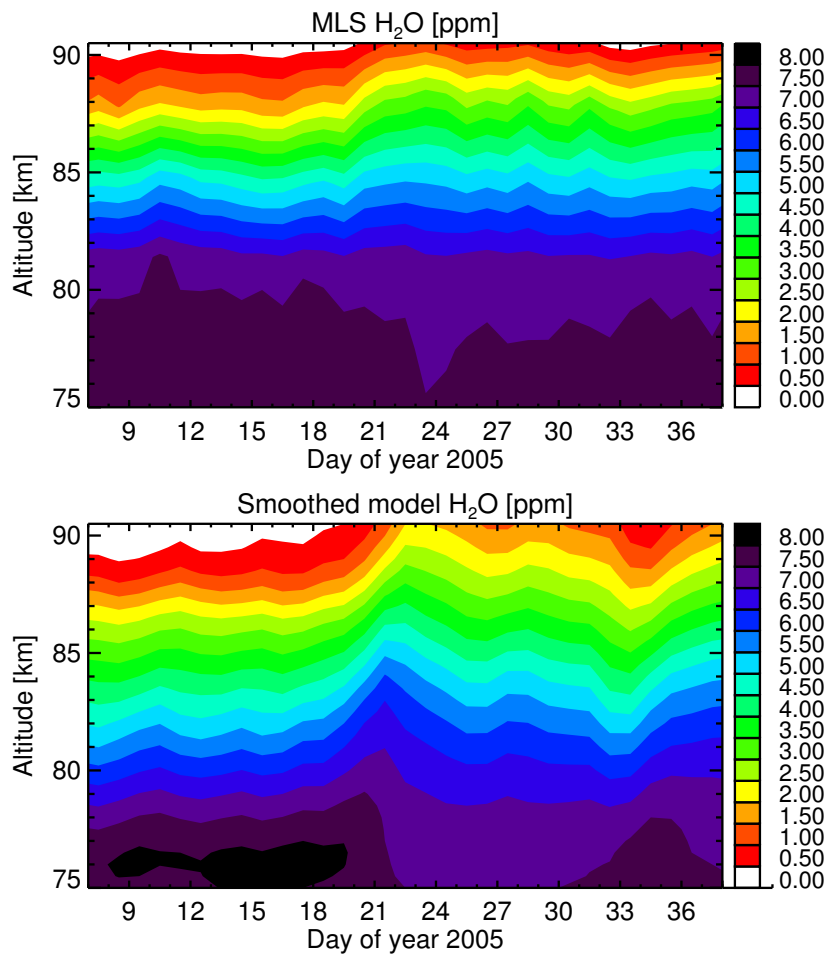

Fig. 8. Water mixing ratio $[\mathrm{ppm}]$ at $75^{\circ} \mathrm{S}$ around the SPE January 2005 . Upper panel: daily mean zonally averaged $\left(70-80^{\circ} \mathrm{S}\right)$ MLS water vapor. Lower panel: model water as in Fig. 7 but smoothed with a $12 \mathrm{~km}$ boxcar function to account for the vertical resolution of the MLS measurements.

Due to the lower water abundance, the modelled icy particle abundance (Fig. 9) is smaller than in the simulations with MLS water, and the recovery on 24-25 January is weaker (compare Fig. 9 and Fig. 5). The agreement with the NLC occurrence rate can be improved by further reducing the temperatures, e.g. by $5 \mathrm{~K}$ (not shown). From this indirect comparison, incorporating MLS temperatures, it should not be concluded that the MLS $\mathrm{H}_{2} \mathrm{O}$ mixing ratios at $75 \mathrm{~km}$ are closer to the "true value" than the MIPAS data. The only conclusion is: provided that $\mathrm{H}_{2} \mathrm{O}$ at $75 \mathrm{~km}$ is $5.5 \mathrm{ppm}$ (MIPAS), the model temperatures have to be lower ( $\sim$ MLS minus $5 \mathrm{~K})$ than in the MLS case $(\sim 7.5 \mathrm{ppm}$; $\sim$ MLS minus $2 \mathrm{~K}$ ). It has to be taken into account that the MLS mesopause altitude is about $4 \mathrm{~km}$ higher than the MIPAS mesopause altitude (García-Comas et al., 2011). This might cause the difference between MIPAS and MLS water. A comparison of the MIPAS water measurements with smoothed model results can be seen in Fig. 10. Unfortunately, MIPAS data are only available for a few days in January 2005. Before the SPE, during the days 10-13 January there is good agreement between the smoothed model data and MIPAS $\mathrm{H}_{2} \mathrm{O}$. For 2122 January, MIPAS shows slightly increased water mixing ratios, especially at altitudes $84-87 \mathrm{~km}$. The water decrease at lower altitudes at the same time predicted by the model

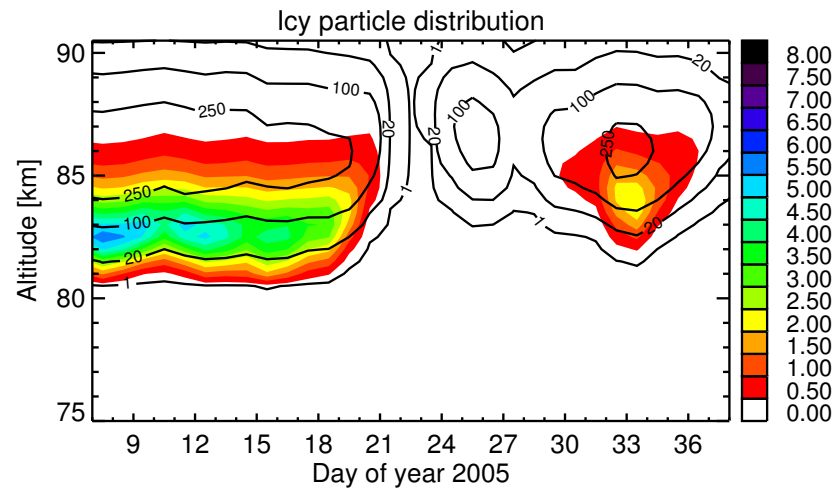

Fig. 9. Same as Fig. 5 but here for a model run with $5.5 \mathrm{ppm} \mathrm{H}_{2} \mathrm{O}$ at $75 \mathrm{~km}$ corresponding to the MIPAS value.

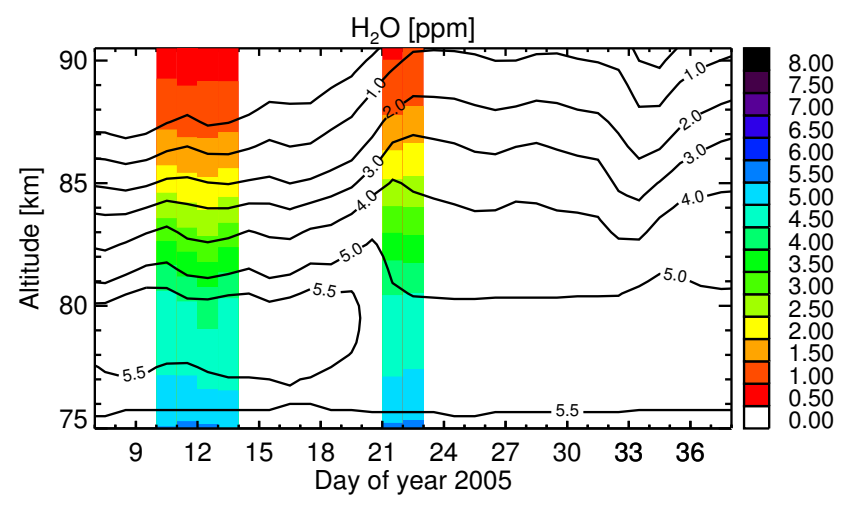

Fig. 10. Water mixing ratio [ppm] around the SPE January 2005 corresponding to Fig. 9. The filled color contours at days 10-13 and 21-22 show daily mean MIPAS water $\left(70-80^{\circ} \mathrm{S}\right)$ and the contour lines show the model $\mathrm{H}_{2} \mathrm{O}$ smoothed with a $6 \mathrm{~km}$ boxcar function to account for the vertical resolutions of the MIPAS measurements.

is not present in the MIPAS data. Again, this discrepancy might be attributed to missing transport processes in the onedimensional model.

Although the model simulations indicate that the increasing temperatures after the SPE nicely explain the observed decrease of NLCs, additional ion chemistry simulations have been undertaken to study the effect of the ion-induced water depletion. The total charge density during the SPE is displayed in Fig. 11. While the charge density exceeds $10^{5} \mathrm{~cm}^{-3}$ at high altitudes, it is significantly smaller below $\sim 83 \mathrm{~km}$. The relative abundances of the most important ion species are shown in Fig. 12. During the SPE, the contribution of charged icy particles is small, and their effect on the ion chemistry is negligible. Proton hydrates, which drive the ion chemical water depletion, are a significant fraction of the total charge density below $\sim 80 \mathrm{~km}$ but their abundance decreases significantly with altitude. As a consequence, the water depletion rate is small above approximately $83 \mathrm{~km}$, see Fig. 13. The resulting effect on the icy particles is shown in Fig. 14. It is small compared to the temperature impact 


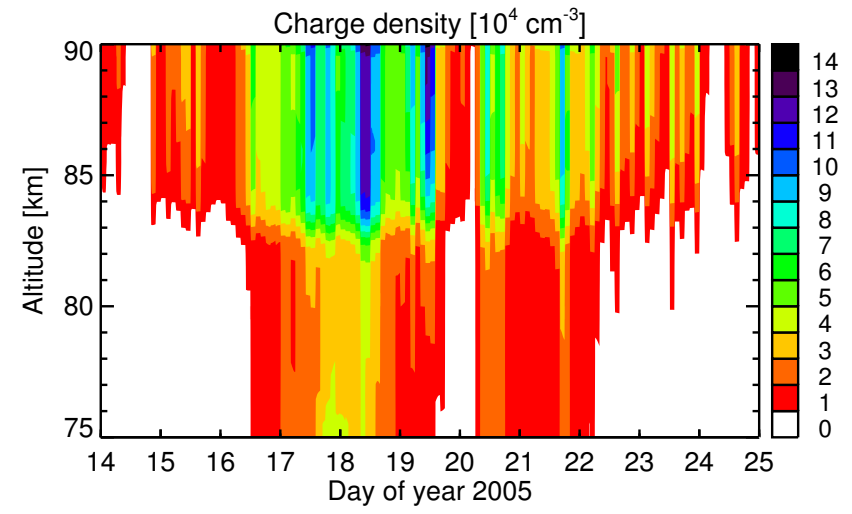

Fig. 11. Modelled total charge density during the SPE January 2005 at $75^{\circ} \mathrm{S}$.

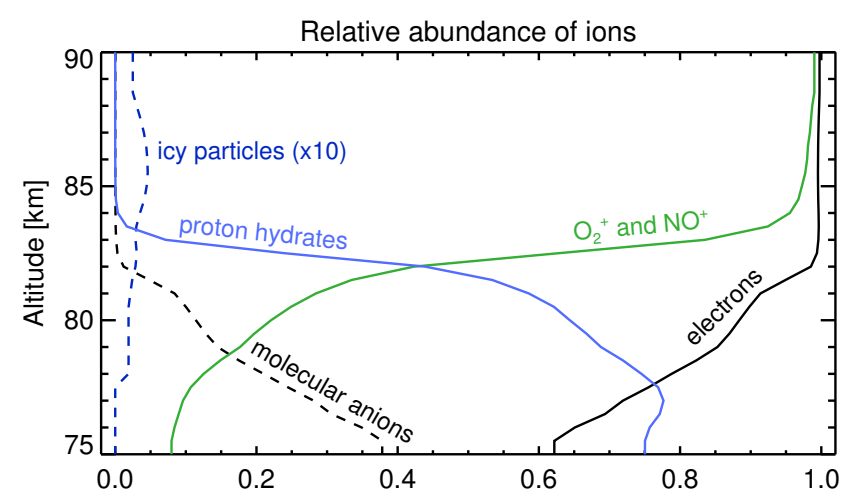

Fig. 12. Modelled daily mean relative abundance of the most important ions as a function of altitude on 18 January at $75^{\circ} \mathrm{S}$. Note that the ratio of negatively charged icy particles is increased by a factor of ten.

(Fig. 5). Figure 15 shows the $\mathrm{H}_{2} \mathrm{O}$ difference between a model run with ion chemistry and a model run without ion chemistry. The effect is clearly smaller than the water redistribution caused by the temperature induced sublimation of the icy particles (Fig. 7). The smoothed model water from the ion chemistry run does basically not differ from the model run without ion chemistry and is therefore not shown. Finally, Fig. 16 compares the icy particle column and the ice column from model runs with and without ion chemistry. There is only a small additional decrease of icy particles due to the ion chemical water depletion, largest on 18 January when the ionisation rate is highest. Compared to the temperature impact, the effect of ion induced water loss on the icy particles is small for the considered SPE, e.g. changing the MLS temperature by $2 \mathrm{~K}$ has a larger effect on the icy particles than the ion chemical water loss.

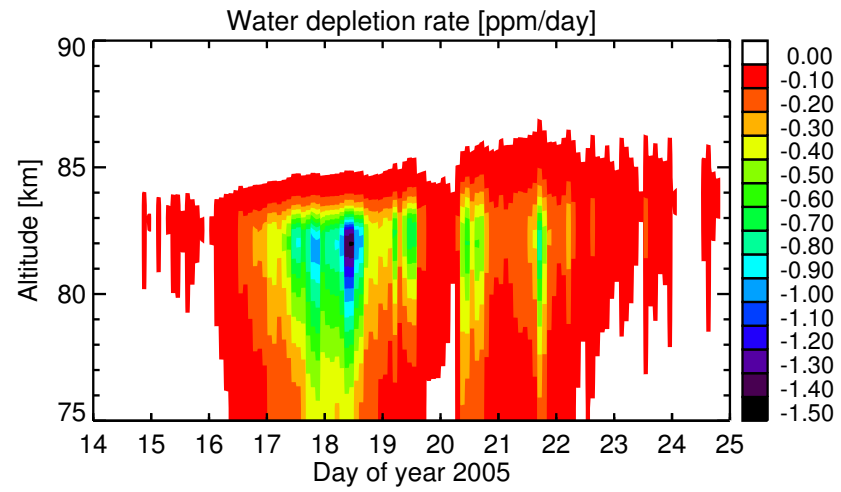

Fig. 13. The modelled rate of water depletion at $75^{\circ} \mathrm{S}$ in units of ppm per day due to ion chemistry.

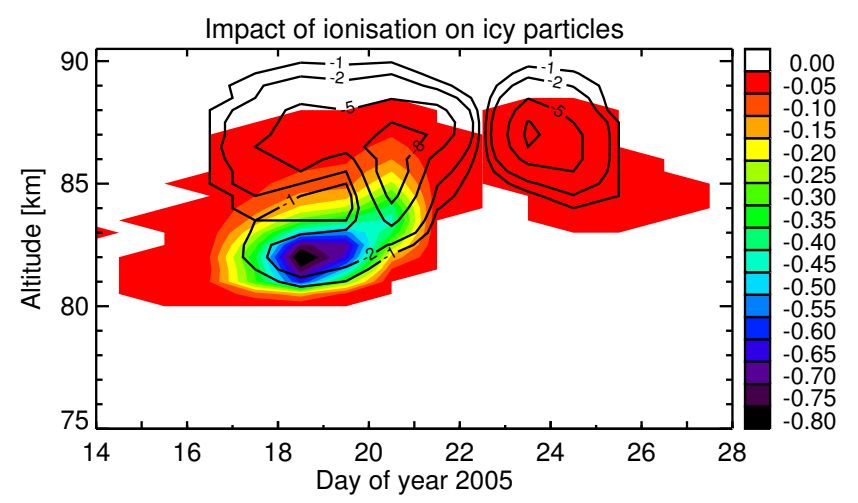

Fig. 14. Daily mean difference between a model run with ion chemistry and a model run without ion chemistry at $75^{\circ} \mathrm{S}$. The negative values correspond to less icy particles due to ion chemical water depletion. The solid contour lines show the difference of the total number of icy particles per $\mathrm{cm}^{3}$, and the color contours depict the difference in the ice mass in units of $10^{-15} \mathrm{~g} \mathrm{~cm}^{-3}$.

\section{Summary and conclusions}

It was shown that the one-dimensional model of icy particles is able to reproduce the observed decrease of NLCs after the SPE of January 2005 if MLS temperatures are used. The governing effect is the sublimation of icy particles due to increasing temperatures. Additionally, model calculations indicate that reactions of proton hydrates lead to a depletion of water which in turn reduces the growth rate of icy particles or facilitates their sublimation. But due to the fact that the abundance of proton hydrates is small in the growth region of the icy particles, the impact of the ion chemical water depletion on NLC occurrence is small compared to the temperature effect. In order to cause a greater impact, the ionisation rates below $\sim 83 \mathrm{~km}$ would have to be higher than during the SPE considered here. Corresponding to the decrease of icy particles during and after the SPE, the model indicates there are considerable changes of the water profile. Before the SPE, the freeze-drying of the NLC layer and the redistribution 


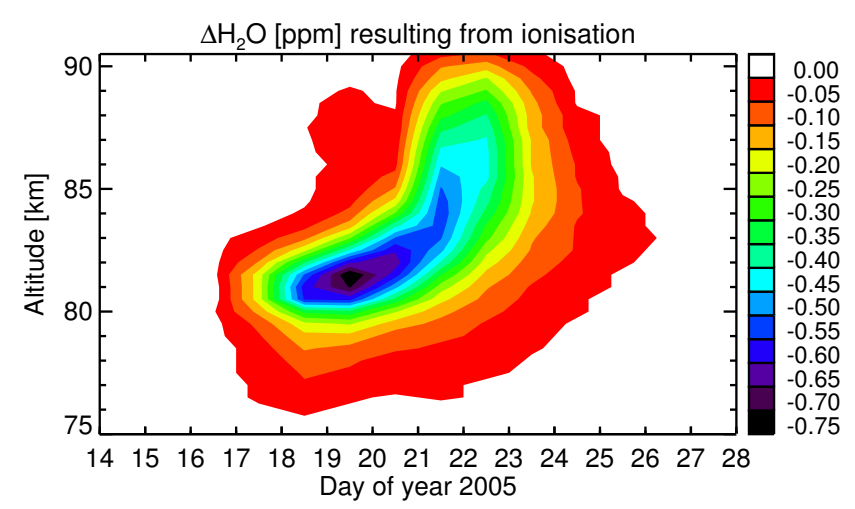

Fig. 15. Difference of the water mixing ratio [ppm] at $75^{\circ} \mathrm{S}$ between a model run with ion chemistry and a model run without ion chemistry. The negative values correspond to the ion chemical water depletion.
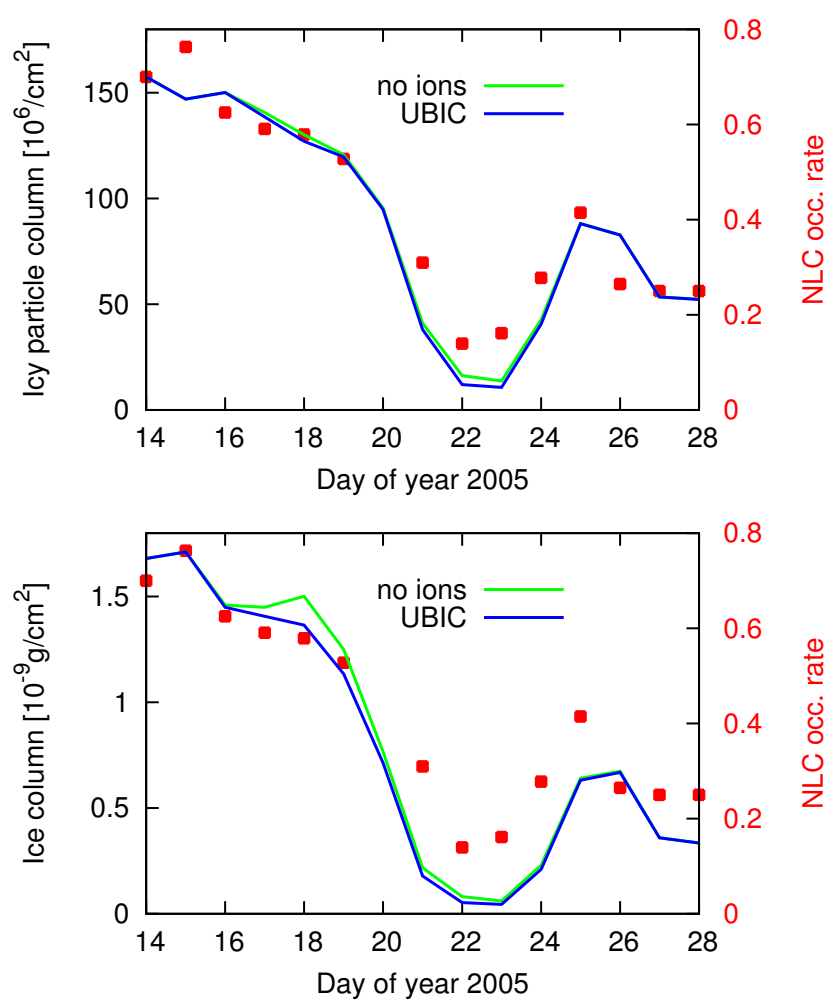

Fig. 16. Upper panel: total column of icy particles in units of $10^{6} \mathrm{~cm}^{-2}$ for (green) simulation without ion chemistry, and (blue) simulation including the ion chemistry model (UBIC) at $75^{\circ} \mathrm{S}$ as well as (red dots) the SCIAMACHY daily mean NLC occurrence rate $\left(70-80^{\circ} \mathrm{S}\right)$. Lower panel: as the upper one but showing the total ice column in units of $10^{-9} \mathrm{~g} \mathrm{~cm}^{-2}$.

of water to lower altitudes leads to an $\mathrm{H}_{2} \mathrm{O}$ mixing ratio of 11 ppm just below the NLC layer (an enhancement by a factor $\sim 2$ ) and to a decrease at higher altitudes (by more than one magnitude at $86 \mathrm{~km}$ ). Even if the vertical resolution of the MLS and MIPAS water measurements are taken into ac- count, there are significant differences between the observed and the modelled water distribution especially just below the icy particle layer. The model predicts stronger gradients and more pronounced changes during the SPE than observed by the satellite instruments. This might be attributed to the simple one-dimensional model approach which in particular neglects inhomogeneities and horizontal transport processes.

Acknowledgements. This work is financially supported by the German Research Council (Deutsche Forschungsgemeinschaft - DFG) within its priority programme CAWSES (Climate and Weather of the Sun-Earth System), and the University of Bremen (ZF 01/811/10). Work at the Jet Propulsion Laboratory, California Institute of Technology, was carried out under a contract with the National Aeronautics and Space Administration. We thank Karl W. Hoppel from the Naval Research Laboratory, Washington, D.C., USA, for providing access to the NOGAPS-ALPHA data.

Edited by: F.-J. Lübken

\section{References}

Andrews, D. G., Holton, J. R., and Leovy, C. B.: Middle Atmosphere Dynamics, Academic Press, 1987.

Bardeen, C. G., Toon, O. B., Jensen, E. J., Marsh, D. R., and Harvey, V. L.: Numerical simulations of the three-dimensional distribution of meteoric dust in the mesosphere and upper stratosphere, J. Geophys. Res., 113, D17202, doi:10.1029/2007JD009515, 2008.

Bardeen, C. G., Toon, O. B. , Jensen, E. J., Hervig, M. E., Randall, C. E. Benze, S., Marsh, D. R., and Merkel, A: Numerical simulations of the three-dimensional distribution of polar mesospheric clouds and comparisons with Cloud Imaging and Particle Size (CIPS) experiment and the Solar Occultation For Ice Experiment (SOFIE) observations, J. Geophys. Res., 115, D10204, doi:10.1029/2009JD012451, 2010.

Becker, E. and von Savigny, C.: Dynamical heating of the polar summer mesopause induced by solar proton events, J. Geophys. Res., 115, D00I18, doi:10.1029/2009JD012561, 2010.

Berger, U. and von Zahn, U.: Icy particles in the summer mesopause region: Three-dimensional modeling of their environment and two-dimensional modeling of their transport, J. Geophys. Res., 107, 1366, doi:10.1029/2001JA000316, 2002.

Bjarnason, G. G.: The infulence of atmospheric thermal tides on diurnal variations in chemical constituents in the mesosphere, Ph.D. thesis, University of Colorado, Boulder, 1987.

Bovensmann, H., Burrows, J. P., Buchwitz, M., Frerick, J., Noël, S., Rozanov, V. V., Chance, K. V., and Goede, A. P. H.: SCIAMACHY: Mission objectives and measurement modes, J. Atmos. Sci., 56, 127-150, 1999.

Chu, X., Gardner, C. S., and Papen, G.: Lidar Observations of Polar Mesospheric Clouds at the South Pole: Diurnal Variations, Geophys. Res. Lett., 28, 1973-1940, 2001.

Chu, X., Gardner, C. S., and Roble, R. G.: Lidar studies of interannual seasonal, and diurnal variations of polar mesospheric clouds at the South Pole, J. Geophys. Res., 108, 8447, doi:10.1029/2002JD002524, 2003.

Eckermann, S. D., Hoppel, K. W., Coy, L. McCormack, J. P., Siskind, D. E., Nielsen, K., Kochenash, A., Stevens, M. H., En- 
glert, C. R., Singer, W., and Hervig, M.: High-altitude data assimilation system experiments for the northern summer mesosphere season of 2007, J.Atmos. Solar-Terr. Phys., 71, 531-551, doi:10.1016/j.jastp.2008.09.036, 2009.

Fletcher, C. A. J.: Computational Techniques for Fluid Dynamics, Volume I, 2nd edn. p. cm. - (Springer series on computational physics), Springer-Verlag Berlin, Heidelberg, New York, 1988.

Forbes, J. M. and Gillette, D. F.: A compendium of theoretical atmsopheric tidal structures, AFGL Tech. Rep. 82-0173(1), Air Force Geophys. Lab., Bedford, Mass., 1982.

Friedrich, M. and Torkar, K. M.: Emperical transition heights of cluster ions, Adv. Space Res., 8, 4235-4238, 1988.

Gadsden, M.: Noctilucent clouds seen at $60^{\circ} \mathrm{N}$ : Origin and development, J. Atmos. Sol. Terr. Phy., 60, 1763-1772, 1998.

García-Comas, M., Funke, B., López-Puertas, M., BermejoPantaleón, D., Glatthor, N., von Clarmann, T., Stiller, G., Grabowski, U., Boone, C. D., French, W. J. R., Leblanc, T., López-González, M. J., and Schwartz, M. J.: On the quality of MIPAS kinetic temperature in the middle atmosphere, Atmos. Chem. Phys. Discuss., 11, 24233-24312, doi:10.5194/acpd-1124233-2011, 2011.

Gumbel, J. and Megner, L.: Charged meteoric smoke as ice nuclei in the mesosphere: Part 1 - A review of basic concepts, J. Atmos. Sol. Terr. Phy., 71, 1225-1235, 2009.

Gumbel, J. and Witt, G.: Cluster ions and ice particle nucleation: Positive feedback at the summer mesopause, Geophys. Res. Lett., 29, 1782, doi:10.1029/2002GL015146, 2002.

Gumbel, J., Siskind, D. E., Witt, G., Torkar, K. M., and Friedrich, M.: Influence of ice particles on the ion chemistry of the polar summer mesosphere, J. Geophys. Res., 108, 8436, doi:10.1029/2002JD002413, 2003.

Hale, B. N. and Plummer, P. L. M.: Molecular model of ice clusters in a supersaturated vapour, J. Chem. Phys., 61, 4012-4019, 1974.

Hervig, M. E. and Gordley, L. L.: Temperature, shape, and phase of mesospheric ice from Solar Occultation for Ice Experiment observations, J. Geophys. Res., 115, D15208, doi:10.1029/2010JD013918, 2010.

Hervig, M. and Siskind, D.: Decadal and inter-hemispheric variability in polar mesospheric cloud, water vapour, and temperature, J. Atmos. Sol. Terr. Phy., 68, 30-41, doi:10.1016/j.jastp.2005.08.010, 2006.

Hesstvedt, E.: Note on the nature of noctilucent clouds, J. Geophys. Res., 66, 1985-1987, 1961.

Hoppel, K. W., Baker, N. L., Coy, L., Eckermann, S. D., McCormack, J. P., Nedoluha, G. E., and Siskind, D. E.: Assimilation of stratospheric and mesospheric temperatures from MLS and SABER into a global NWP model, Atmos. Chem. Phys., 8, 6103-6116, doi:10.5194/acp-8-6103-2008, 2008.

Hunten, D. M., Turco, R. P., and Toon, O. B.: Smoke and dust particles of meteoric origin in the mesosphere and stratosphere, J. Atmos. Sci., 37, 1342-1357, 1980.

Jensen, E. J. and Thomas, G. E.: A Growth-Sedimentation Model of Polar Mesospheric Clouds: Comparison With SME Measurements, J. Geophys. Res., 93, 2461-2473, 1988.

Jensen, E. J., Thomas, G. E., and Toon, O. B.: On the Diurnal Variation of Noctilucent Clouds, J. Geophys. Res., 94, 14693-14702, 1989.

Keesee, R. G.: Nucleation and Particle Formation in the Upper Atmosphere, J. Geophys. Res., 94, 14683-14692, 1989.
Klostermeyer, J.: A simple model of the ice particle size distribution in noctilucent clouds, J. Geophys. Res., 103, 28743-28752, 1998.

Lambert, A., Read, W. G., Livesey, N. J., Santee, M. L., Manney, G. L., Froidevaux, L., Wu, D. L., Schwartz, M. J., Pumphrey, H. C., Jimenez, C., Nedoluha, G. E., Cofield, R. E., Cuddy, D. T., Daffer, W. H., Drouin, B. J., Fuller, R. A., Jarnot, R. F., Knosp, B. W., Pickett, H. M., Perun, V. S., Snyder, W. V., Stek, P. C., Thurstans, R. P., Wagner, P. A., Waters, J. W., Jucks, K. W., Toon, G. C., Stachnik, R. A., Bernath, P. F., Boone, C. D., Walker, K. A., Urban, J., Murtagh, D., Elkins, J. W., and Atlas, E.: Validation of the Aura Microwave Limb Sounder stratospheric water vapor and nitrous oxide measurements, J. Geophys. Res., 112, D24S36, doi:10.1029/2007JD008724, 2007.

Lau, Y. K., Ikuta, S., and Kebarle, P.:, Thermodynamics and Kinetics of the Gas-Phase Reactions: $\mathrm{H}_{3} \mathrm{O}^{+}\left(\mathrm{H}_{2} \mathrm{O}\right)_{n-1}+\mathrm{H}_{2} \mathrm{O}=$ $\mathrm{H}_{3} \mathrm{O}^{+}\left(\mathrm{H}_{2} \mathrm{O}\right)_{n}$, J. Am. Chem. Soc., 104, 1462-1469, 1982.

Laven, P.: Simulation of rainbows, coronas, and glories by use of Mie theory, Appl. Optics, 42, 436-444, 2003.

Leu, M. T., Biondi, M. A., and Johnsen, R.: Measurements of the Recombination of Electrons with $\mathrm{H}_{3} \mathrm{O}^{+} \cdot\left(\mathrm{H}_{2} \mathrm{O}\right)_{n}$-Serie Ions, Phys. Rev. A, 7, 292-298, 1973.

Lübken, F.-J.: Seasonal variation of turbulent energy dissipation rates at high latitudes as determined by in situ measurements of neutral density fluctuations, J. Geophys. Res., 102, 1344113456, doi:10.1029/97JD00853, 1997.

Lübken, F.-J., Lautenbach, J., Höffner, J., Rapp, M., and Zecha, M.: First continuous temperature measurements within polar mesosphere summer echos, J. Atmos. Sol. Terr. Phy., 71, 453-463, 2009.

Megner, L.: Minimal impact of condensation nuclei characteristics on observable Mesospheric ice properties, J. Atmos. Sol. Terr. Phy., 73, 2184-2191, doi:10.1016/j.jastp.2010.08.006, 2010.

Megner, L. and Gumbel, J.: Charged meteoric smoke as ice nuclei in the mesosphere: Part 2 - A feasibility study, J. Atmos. Sol. Terr. Phy., 71, 1236-1244, doi:10.1016/j.jastp.2009.05.002, 2009.

Megner, L., Siskind, D. E., Rapp, M., and Gumbel, J.: Global and temporal distribution of meteoric smoke: A twodimensional simulation study, J. Geophys. Res., 113, D03202, doi:10.1029/2007JD009054, 2008.

Mlynczak, M. G. and Russell, J. M. III: An overview of the SABER experiement for the TIMED mission, Optical Remote Sensing of the Atmosphere, 2, OSA Technical digest Series, Washington, D.C., 5-7, 1995.

Murphy, D. M. and Koop, T.: Review of the vapour pressure of ice and supercooled water for atmospheric applications, Q. J. Roy. Meteorol. Soc., 131, 1539-1565, 2005.

Murray, B. J. and Jensen, E. J.: Homogeneous nucleation of amorphous solid water particles in the upper mesosphere, J.Atmos. Solar-Terr. Phys., 72, 51-61, doi:10.1016/j.jastp.2009.10.007, 2010.

Murray, B. J. and Plane, J. M. C.: Modelling the impact of noctilucent cloud formation on atomic oxygen and other minor constituents of the summer mesosphere, Atmos. Chem. Phys., 5, 1027-1038, doi:10.5194/acp-5-1027-2005, 2005.

Pruppacher, H. R. and Klett, J. D.: Microphysics of clouds and precipitation, 2 edn., Springer, The Netherlands, 1997.

Rahpoe, N., von Savigny, C., Robert, C. E., DeLand, M. T., and Burrows, J. P.: Impact of solar proton events on noc- 
tilucent clouds, J. Atmos. Sol. Terr. Phy., 73, 2073-2081, doi:10.1016/j.jastp.2010.07.017, 2011.

Rapp, M., and Thomas, G. E.: Modeling the microphysics of mesospheric ice particles: Assessment of current capabilities and basic sensitiveties, J. Atmos. Sol. Terr. Phy., 68, 715-744, doi:10.1016/j.jastp.2005.10.015, 2006.

Read, W. G., Lambert, A., Bacmeister, J., Cofield, R. E., Cuddy, D. T., Daffer, W. H., Drouin, B. J., Fetzer, E., Froidevaux, L., Fuller, R., Herman, R., Jarnot, R. F., Jiang, J. H., Jiang, Y. B., Kelly, K., Knosp, B. W., Kovalenko, L. J., Livesey, N. J., Liu, H.-C., Manney, G. L., Miller, D., Mills, B. J., Pickett, H. M., Pumphrey, H. C., Rosenlof, K. H., Sabounchi, X., Santee, M. L., Schwartz, M. J., Snyder, W. V., Stek, P. C., Su, H., Takacs, L. L., Thurstans, R. P., Vömel, H., Wagner, P. A., Waters, J. W., Webster, C. R., Weinstock, E. M., and Wu, D. L.: EOS Aura Microwave Limb Sounder upper tropospheric and lower stratospheric humidity validation, J. Geophys. Res., 112, D24S35, doi:10.1029/2007JD008752, 2007.

Reid, G. C.: Ice clouds at the summer polar mesopause, J. Atmos. Sci., 32, 523-535, 1975.

Reid, G. C.: Ice Particles and Electron "Bite-Outs" at the Summer Polar Mesopause, J. Geophys. Res., 95, 13891-13896, 1990.

Robert, C. E., von Savigny, C., Burrows, J. P., and Baumgarten, G.: Climatology of noctilucent cloud radii and occurrence frequency using SCIAMACHY, J. Atmos. Sol. Terr. Phy., 71, 408423, doi:10.1016/j.jastp.2008.10.015, 2009.

Rusch, D. W., Thomas, G. E., and Jensen, E. J.: Particle size distributions in polar mesopsheric clouds derived from Solar Mesosphere Explorer measurements, J. Geophys. Res., 96, 1293312939, 1991.

Schwartz, M. J., Lambert, A., Manney, G. L., Read, W. G., Livesey, N. J., Froidevaux, L., Ao, C. O., Bernath, P. F., Boone, C. D., Coield, R. E., Daffer, W. H., Drouin, B. J., Fetzer, E. J., Fuller, R. A., Jarnot, R. F., Jiang, J. H., Jiang, Y. B., Knosp, B. W., Krüger, K., Li, J.-L. F., Mlynczak, M. G., Russell, III, J. M., Santee, M. L., Snyder, W. V., Stek, P. C., Thurstans, R. P., Tompkins, A. M., Wagner, P. A., Walker, K. A., Waters, J. W., and Wu, D. L.: Validation of the Aura Microwave Limb Sounder temperature and geopotential height measurements, J. Geophys. Res., 113, D15S11, doi:10.1029/2007JD008783, 2008.

Singer, W., Bremer, J., Hocking, W. K., Weiß, J., Latteck, R., and Zecha, M.: Temperature and wind tides around the summer mesopause at middle and Arctic latitudes, Adv. Space Res., 31, 2055-2060, doi:10.1016/S0273-1177(03)00228-X, 2003.

Singer, W., Latteck, R., Hoffmann, P., Williams, B. P., Fritts, D. C., Murayama, Y., and Sakanoi, K.: Tides near the arctic summer mesopause during the macwave/midas summer program, Geophys. Res. Lett., 32, L07S90, doi:10.1029/2004GL021607, 2005.

Skinner, L. M. and Sambles, J. R.: The Kelvin equation - a review, J. Aerosol Sci., 3, 199-210, doi:10.1016/0021-8502(72)90158-9, 1970.

Solomon, S., Rusch, D. W., Gérard, J. C., Reid, G. C., and Crutzen, P. J.: The effect of particle precipitation events on the neutral and ion chemistry of the middle atmosphere: II. Odd hydrogen, Planet. Space Sci., 29, 885-893, doi:10.1016/00320633(81)90078-7, 1981

Stevens, M. H., Siskind, D. E., Eckermann, S. D., Coy, L. McCormack, J. P., Englert, C. R., Hoppel, K. W. Nielsen, K. Kochenash, A. J., Hervig, M. E., Randall, C. E., Lumpe, J., Bailey, S. M.,
Rapp, M., and Hoffmann, P.: Tidally induced variations of PMC altitudes and ice water content using a data assimilation system, J. Geophys. Res., 115, D18209, doi:10.1029/2009JD013225, 2010.

Thomas, G. E., Olivero, J. J., Jensen, E. J., Schroeder, W., and Toon, O. B.: Relation between increasing methane and the presence of ice clouds at the mesopause, Nature, 338, 490-492, doi:10.1038/338490a0, 1989.

Tolman, R. C.: The Effect of Droplet Size on Surface Tension, J. Chem. Phys., 17, 333-337, 1949.

Toon, O. B., Turco, R. P., Westphal, D., Malone, R., and Liu, M. S.: A Multidimensional Model for Aerosols: Description of Computational Analogs, J. Atmos. Sci., 45, 2123-2143, 1988.

Turco, R. P., Toon, O. B., Whitten, R. C., Keesee, R. G., and Hollenback, D.: Noctilucent clouds: Simulation studies of their genesis, properties, and global influences, Planet. Space Sci., 30, $1147-$ $1181,1982$.

Ulwick, J. C., Baker, K. D., Kelley, M. C., Balsley, B. B., and Ecklund, W. L.: Comparison of Simultaneous MST Radar and Electron Density Probe Measurements During STATE, J. Geophys. Res., 93, 6989-7000, 1988.

von Clarmann, T., Glatthor, N., Grabowski, U., Höpfner, M., Kellmann, S., Kiefer, M., Linden, A., Tsidu, G. M., Milz, M., Steck, T., Stiller, G. P., Wang, D. Y., Fischer, H., Funke, B., GilLópez, S., and López-Puertas, M.: Retrieval of temperature and tangent altitude pointing from limb emission spectra recorded from space by the Michelson Interferometer for Passive Atmospheric Sounding (MIPAS), J. Geophys. Res., 108, 4736, doi:10.1029/2003JD003602, 2003.

von Cossart, G., Fiedler, J., and von Zahn, U.: Size distributions of NLC particles as determined from 3-colour observations of NLC by ground-based lidar, Geophys. Res. Lett., 26, 1513-1516, 1999.

von Savigny, C., Kokhanovsky, A., Bovensmann, H., Eichmann, K.U., Kaiser, J., Nöel, S., Rozanov, A. V., Skupin, J., and Burrows, J. P.: NLC detection and particle size determination: first results from SCIAMACHY on ENVISAT, Adv. Space Res., 34, 851856, doi:10.1016/j.asr.2003.05.050, 2004.

von Savigny, C., Sinnhuber, M., Bovensmann, H., Burrows, J. P., Kallenrode, M.-B., and Schwartz, M.: On the disappearance of noctilucent clouds during the January 2005 solar proton events, Geophys. Res. Lett., 34, L02805, doi:10.1029/2006GL028106, 2007.

von Zahn, U. and Berger, U.: Persistent ice cloud in the midsummer upper mesosphere at high altitudes: Three-dimensional modeling and cloud interactions with ambient water vapor, J. Geophys. Res., 108, 8451, doi:10.1029/2002JD002409, 2003.

von Zahn, U., von Cossart, G., Fiedler, J., and Rees, D.: Tidal variations of noctilucent clouds measured at $69^{\circ} \mathrm{N}$ latitude by groundbased lidar, Geophys. Res. Lett., 25, 1289-1292, 1998.

von Zahn, U., Baumgarten, G., Berger, U., Fiedler, J., and Hartogh, P.: Noctilucent clouds and the mesospheric water vapour: the past decade, Atmos. Chem. Phys., 4, 2449-2464, doi:10.5194/acp-42449-2004, 2004.

Warren, S.: Optical constants of ice from ultraviolet to the microwave, Appl. Optics, 23, 1206-1225, 1984.

Winkler, H., Kazeminejad, S., Sinnhuber, M., Kallenrode, M.B., and Notholt, J.: Conversion of mesospheric $\mathrm{HCl}$ into active chlorine during the solar proton event in July 2000 in 
the northern polar region, J. Geophys. Res., 114, D00I03, doi:10.1029/2008JD011587, 2009.
Wissing, J. M. and Kallenrode, M.-B.: Atmospheric Ionization Module Osnabrück (AIMOS): A 3-D model to determine atmospheric ionization by energetic charged particles from different populations, J. Geophys. Res., 114, A06104, doi:10.1029/2008JA013884, 2009. 